\title{
Titel/Title: Freelancers in Germany's Old and New Media Industry: Beyond Standard Patterns of Work and Life?
}

Autor*innen/Author(s): Annette Henninger

Karin Gottschall

Veröffentlichungsversion/Published version: Postprint

Zeitschriftenartikel/Journal article

\section{Empfohlene Zitierung/Recommended citation:}

Henninger, Annette, and Karin Gottschall. "Freelancers in Germany's Old and New Media Industry: Beyond Standard Patterns of Work and Life?" Critical Sociology, vol. 33, no. 1-2, Jan. 2007, pp. 43-71, doi:10.1163/156916307X168584.

Verfügbar unter/Available at:

(wenn vorhanden, bitte den DOI angeben/please provide the DOI if available)

https://doi.org/10.1163/156916307X168584

Zusätzliche Informationen/Additional information:

The author can be contacted at: karin.gottschall@uni-bremen.de 


\title{
Freelancers in Germany's Old and New Media Industry: Beyond Standard Patterns of Work and Life?*
}

Annette Henninger and Karin Gottschall

\begin{abstract}
The paper addresses potential changes in the patterns of work and private life among freelancers in Germany's media industry (journalists, designers, software developers). In the first step, we analyze how freelance workers have been integrated into Germany's regulations for the labor market. Our analysis points to important differences between the professional groups. In a second step, we ask whether freelancers in the German media industry fit the picture of workaholics. Our interviews with freelancers show that only a minority has thoroughly blurred the boundaries between work and life, while most others still draw a clear line between the two. Findings on partnerships reveal that structurally equal dual-earner arrangements are widespread, but are not the only type of gender arrangement. An important group opts for structurally specialized arrangements based on traditional as well as reversed gender roles. In the final discussion we assess to what extent German trends in the changing patterns of work and life converge with those in the US and in the UK.
\end{abstract}

\section{Keywords}

Gender, work, work-life balance, regulation, labor markets, media industry

* Our paper draws on results from a research project funded by the German Federal Ministry of Education and Research. We thank Harald Wolf and two anonymous reviewers for valuable comments. $(\leftarrow$ p. 43)

\section{Introduction: New Forms of Work, New Patterns of Work and Life?}

As a part of the expanding knowledge-based service sector in capitalist societies, the media industry is characterized by a high proportion of freelancers and small companies. In the public discourse surrounding the global new economy, workers in this field have often been portrayed as a postmodern young urban workforce, mostly singles, totally committed to their highly innovative work, adhering to a 'boundaryless career' of professional independence and entrepreneurial thinking, thus forecasting a broader change towards a new 'knowledge society'. Within this discourse, in both its public and academic strands, the line between empirical analysis and visionary projection became blurred. Meanwhile the crisis of the new economy led many to adopt a far more skeptical view of the ways how work lives were changing for most people. In particular, the notion of an all-encompassing trend towards knowledge-intensive and independent forms of work has been corrected.

Still, empirical evidence about freelancing in this field reveals some distinct features which might indicate a new form of work: working conditions are flexible in terms of working hours, income, and place of work. The workforce generally has an academic education, and a high proportion are women. These facts seem to indicate that workers want a professional career that allows for more individual choices about work and life arrangements; but, these 
choices also create needs for a new balance beyond the traditional work-family relations. Thus, in the media industry one might indeed expect to find patterns of work and life that differ in two ways from those typical for standard employment. First, borders between work and life - in terms of time, space and social contacts - might be more permeable or even dissolve. Second, work-life arrangements might be less gendered in that dual-earner arrangements might prevail, rather than the traditional male-breadwinner model.

The issue of dissolving borders - far more than the gender impact of flexible patterns of work and life - has stimulated an ongoing academic debate. In the growing body of research on knowledge-intensive work, the effects of more flexibility on the quality of work and life are controversial. While a more optimistic version, drawing on the concept of portfolio work (Handy 1994), emphasizes the rising potential for individual career building and work-life balance (see for example Gold and $(\leftarrow$ p. 44)Fraser 2002), others stress that work patterns demanding flexibility might decrease individual autonomy regarding workload and work organization and thus threaten the balance of work and life by commercializing the entire context of life (Batt and others 2001; Pongratz and Voß 2003).

Both perspectives, however, share the assumption that, irrespective of national contexts, this type of work implies dissolving borders or a 'delimitation'1 of work and life. This view has some credibility, especially with respect to the global character of the media industry.

However, we question this generalizing notion. We also see the need to address the impact of gender, which is often ignored in analyses of new forms of work. ${ }^{2}$ As we know from comparative research, the 'varieties of capitalism' embody different modes of labor market and work regulation as well as different gender contracts (Crouch and Streeck 1997; Lewis and Ostner 1994). These factors result in path dependencies that tend to impede substantial change. Thus, it becomes less likely that economic globalization - though a supranational trend - will lead to convergence in national patterns of work-life and gender relations.

Instead, we suggest that domestic labor market regulations and gender relations function as a needle's eye through which transnational economic (and political) influences must pass. Thus one might expect an interaction rather than a disruption between existing national patterns and new forms of non-standard work and the accompanying gender arrangements. ${ }^{3}$

In what follows, we address the questions of a de-limitation of work and life and the potential weakening of the male-breadwinner model by presenting empirical findings from a study on freelancers in $(\leftarrow$ p. 45) Germany's old and new media industries, thus filling a gap in the overwhelmingly Anglo-American landscape of case study research on new media workers. ${ }^{4}$ How are freelance workers integrated into Germany's labor market regulations? What mode

\footnotetext{
${ }^{1}$ We use the term 'de-limitation' or 'dis-enclosure' to characterize the dissolution of borders between work and private life - in terms of time, space and social contacts - that have been established for standard employment in the process of industrialization (see e.g. Pongratz and Voß 2003).

${ }^{2}$ For a different approach see Walby and others (2007) and Henninger and Papouschek (2006).

${ }^{3}$ We use the term 'gender relations' to refer to the positions of men and women in society, including the division of paid and unpaid work which is a crucial element of gender hierarchy in most societies. The term 'gender arrangement' is used to describe the division of paid and unpaid work in partnerships.

${ }^{4}$ For recent studies of the UK see Dex and others (2000); Granger, Stanworth and Stanworth (1995); Baumann (2002); Gill (2002); Fraser and Gold (2001) and Perrons (2004; 2005). For empirical evidence from the US see Batt and others (2001), Pratt (2000), Grey and Healy (2004), and Kotamraju (2002). In Germany, research on new media work gained attention only recently (see several contributions in Gottschall and Voß 2003; Wixforth 2003 while research on old media industries and occupations (especially journalism) has a longer tradition (i.e., Rehberg, Stöger and Sträter 2002; Satzer 2001). Comparative studies are rare, see Baumann (2002) for Germany and the UK and Gill (2002) and Perrons and others (2006) for a broader EU comparison.
} 
of governance applies to this non-standard type of work? Do freelancers in the German media industry fit the picture of workaholics to whom the distinction between work and private is life no longer meaningful? And how do they arrange their work and life, especially within their domestic partnerships? That is: what gender arrangements are to be found, including the division of paid and unpaid work? Overall, we examine the extent to which freelancers in the German media industry develop work-life arrangements that lie beyond the standard patterns.

The German media industry provides an interesting case in which to explore these questions, because of national regulations and also trends in both gender arrangements and selfemployment. Unlike the liberal market economies of the US or the UK, German labor and product markets are strongly regulated by corporations and institutions, and the standard employment contract is a crucial point of reference. Concerning gender arrangements, a modernized version of the male-breadwinner model still predominates. In terms of industry and occupations, the old and new media industries are an appropriate area for research, as content, design, and IT-related work are converging (Dostal 2002: 192). Here, selfemployment as an emblematic form of new flexible work can be found in more traditional fields like print journalism and graphic design as well as in new media segments like web journalism, web design and software development. These occupational groups differ in their proportion of freelancers, of men and women in the labor force, and in their bargaining power on the labor market. Thus they provide con- $(\leftarrow$ p. 46$)$ trasting examples for researching the impact of professional labor markets which are central to the constitution of the German labor market. The data for our study were generated using a mix of qualitative and quantitative methods. In a first step we gathered background information on the different occupational groups by using insights from expert interviews, ${ }^{5}$ from an analysis of existing statistical data and from a questionnaire survey $(\mathrm{N}=185)$ among members of professional associations in Berlin, Cologne and Hamburg, three German cities that represent important clusters of the industry. ${ }^{6}$ As representative statistical data on freelancers is scarce, the demographic data collected in our survey provide valuable additional information.

In a second step, during 12 months in 2003 and 2004, we conducted semi-structured, in-depth interviews with 17 freelance journalists, 13 designers and 9 software developers to gain insights into the organization of work and life from an everyday as well as a biographical perspective. We selected interview partners from the questionnaire sample according to a fixed set of sampling criteria. Overall, our findings from the expert interviews support the assumption that the sample covers typical constellations in terms of social structure and market integration.

We begin by situating freelance work and the different occupational groups in the German institutional setting, drawing on our secondary analysis, expert interviews and survey data. We then present results from the analysis of our interview material, focusing on our interview partners' work-life arrangements. In our final discussion we reassess our case study results in

\footnotetext{
${ }^{5} 18$ expert interviews were conducted with representatives of professional organizations, trade unions and specialized research institutions.

${ }^{6}$ Sample recruitment by professional organizations proved to be the only reliable way to address a broad spectrum of self-employed workers covering a market which is mainly characterized by informal governance. This implies a selection since not all workers are members of professional organizations - the degree of organization ranges from about 47 percent in journalism to less than 6 percent in graphic design, for software developers reliable data are missing (see below). Where possible, we checked declinations from representative social structure data.
} 
the broader comparative context asking for trends towards convergence in the changing patterns of work and life. $(\leftarrow$ p. 47)

\section{Freelancing in the German Institutional Setting}

In spite of a trend towards globalized markets for media and IT products, the labor markets in these industries are still influenced by national characteristics (for Germany see Casper, Lehrer and Soskice 1999; Krätke 2002). In Germany, the predominance of a standard employment contract, combined with a male-breadwinner model, led to a specific form of regulation of work and life. A further important characteristic of the German labor market is the system of vocational training and education which regulates the entry of workers into the market, leading to horizontal segregation between occupational groups (Krüger 2003: 37). These national and professional characteristics provide a specific context for freelance work and result in a specific mode of governance.

\section{National Context: Standard Employment and the Male-Breadwinner Model}

In comparative research Germany has been labeled a 'coordinated market economy' (Hall and Soskice 2001) with a gender order that is based on a modernized version of the malebreadwinner model. Crompton (2001: 268) describes a continuum of gender orders starting from the traditional male-breadwinner model and moving towards less traditional dual-earner models that are combined with different care arrangements. Following Crompton's typology, the gender order in Western Germany can be characterized as a modernized version of a malebreadwinner model with a female part-time earner/caregiver. Meanwhile, the gender order in the former GDR, which was characterized by a dual-earner/state caregiver model, remains prevalent as a cultural pattern in Eastern Germany (Dölling 1998). ${ }^{7}$

The West German institutional framework, however, was transferred to Eastern Germany after reunification. In this regulatory framework, the standard employment contract serves as a point of reference for the $(\leftarrow \mathbf{p .} \mathbf{4 8})$ regulation of work and life. The daily life and the life course of the ideal type of a male-breadwinner is structured by a long-term, standard employment contract which binds him to a company and guarantees benefits for himself and his family. At least for men, this employment arrangement strictly separates paid work and leisure, while women are assigned the unpaid work of caring for house and children. Public institutions supply mostly part-time care services, e.g. kindergartens, and half-day schooling. Moreover, the joint taxation of married couples leads to a high marginal tax rate for a secondary income (Dingeldey 2001). Whereas this institutional context implies that men will face little or no problems combining family and paid labor, it leads to particular contradictions for women (Jurczyk and Rerrich 1993; Krüger 2003).

This model of the standard employee served as a blueprint for social and labor market policies in Western Germany after World War II (Gottschall 2002; Leisering 2003). As time passed, it was extended to different groups of self-employed workers. Artists (including journalists and

\footnotetext{
${ }^{7}$ Following Crompton, the gender order in the US can be described as a dual-earner/ marketized caregiver model. There is an ongoing debate where to situate the UK in this typology. Some authors characterize the UK still as an example of the male-breadwinner/ female part-time earner model. However, this model is eroding due to a decline of the family wage and a re-commodification of mothers (Woods 2003).
} 
designers) were the last to be included in the established social system in 1983 through a special nation-wide social insurance scheme (Betzelt and Gottschall 2004). However, this system is selective - for example, software freelancers may not apply - and it provides freelancers only with minimum health and pension insurance. In contrast to the social security system for employees, it includes no unemployment benefits. However, under certain conditions freelancers may qualify for unemployment benefits resulting from a previous standard employment contract.

Thus freelancers in the media industry face high market risks. These risks are not, as one might expect, compensated for by high incomes and institutional self-regulation, as is the case for the classic professions (e.g., doctors, lawyers). While freelancers have made attempts at self-regulation through professional associations, a market monopoly or a sheltered market that constitutes a core element of professionalism (Lane, Potton and Littek 2000: 236) is missing for them. Instead, the freelancers in this industry face a hybrid type of regulation, because they do not fit with either the ideal type of standard employee, or the ideal type of professional (Gottschall 2002). For them, established labor market institutions like certifications and well-defined career paths are weak or nonexistent. Their professional organizations are diverse, and have only a weak influence on the regulation of the market. This makes $(\leftarrow \mathbf{p . 4 9 )}$ labor market transactions insecure and gives way to informal governance. The most prominent social mechanism that captures the informality of market transactions in this field is the trend toward negotiating through network structures which allow some control over communications, trust, and reputations (Haak and Schmid 1999).

Turning to gender arrangements, an interesting parallel exists between the ideal-type standard employee and the ideal-type professional: both are built on the assumption of a family wage, thus fostering the malebreadwinner/female-caregiver arrangement that is the dominant pattern of the German gender order. Freelancers in the media industry, however, might rather turn to dual-earner patterns in order to cope with the high market risks. At the same time, they are subject to the German institutional framework, which supports the male-breadwinner model, for example, by restricted access to public childcare and the joint taxation of couples.

\section{Characteristics of the Professional Labor Markets}

For self-employed workers, market characteristics play an important role in both collective and individual strategies. As research on the classical professions shows, market conditions influence the collective strategies of professional organizations and their ability to selfregulate (Lane, Potton and Littek 2000). A range of market characteristics also influences the individual strategies of freelance knowledge workers (Fraser and Gold 2001). Some characteristics of the labor markets and some strategies of professional associations, merit a brief review here.

\section{Characteristics of the Workforce}

As established media professions, both journalism and design have long-standing traditions of freelance work, ${ }^{8}$ while software development evolved as a profession only in the second half

\footnotetext{
${ }^{8}$ In the GDR, journalists worked as employees in the state media sector, while designers were regarded as artists and allowed to work freelance.
} 
of the 20th century. In contrast to journalists and designers, the overwhelming majority of IT specialists in Germany are employees. Based on a representative sample of the German workforce, Dostal (2002: 203) calculates that 10.6 percent of computer professionals are freelancers, compared to $(\leftarrow$ p. 50) 45.4 percent in the artistic professions (including journalists and designers). Among freelancers in the media sector, long work hours (45-60 hours per week) prevail. In 1997, two thirds of freelancers in this sector worked 40 hours or more, compared to 37 percent of in-house employees. Also, 37 percent of freelancers worked more than 50 hours, compared to 7 percent of in-house employees (Rehberg, Stöger and Sträter 2002: 86). At the same time, the working hours of freelancers oscillate between intense and slack periods, leading to what Pratt (2000: 432) calls "bulimic careers".

While the numbers of workers with an academic education rose considerably over the last decades, the qualification structure of the workforce is still diverse and professional titles are not protected by state regulation. The barriers to market entry are low and all three occupational fields witnessed a substantive rise in the workforce during the last decade. ${ }^{9}$ However, due to different characteristics of the labor markets, this trend had different consequences for each of the three professional groups.

A uniquely German assumption affecting journalists is that media production is of public interest. This led to the establishment of a public media sector which is regulated by state legislation. In the mid-1980s, market deregulation allowed a private sector to emerge (for TV, see Windeler, Lutz and Wirth 2000: 182). During the 1990s, the breakdown of the former state media sector of the GDR as well as outsourcing strategies and mergers among important employers led to a decrease in standard employment. In the field of design, according to estimates until the mid-1990s, two thirds of the workforce were employees in advertising companies, advertising departments or design ateliers. In the second half of the 1990s, the introduction of IT led to a major rationalization of the printing process and several previously separate tasks and professions merged with design. The outsourcing strategies of advertising companies led to a further decrease in standard employment. $(\leftarrow \mathbf{p . ~ 5 1 )}$

In both professional fields, the rise of a new media industry could not compensate for the general decrease in standard employment (for online journalism, see Löffelholz and others 2003). After a short boom in the late 1990s, the 2001 crisis led to layoffs for a high proportion of those holding the new jobs in content and design (Wixforth 2003). Thus, due to labor market pressures, many journalists and designers began to see freelancing as their only alternative to enter, or to stay in, the market. So far, this has not led to increased feminization in these professional fields, both of which have a high proportion of women employees. ${ }^{10}$ Most freelance journalists and designers work as full-service providers who deliver a complete product that has been outsourced from the production chain. Thus, most are only slightly integrated into a customer organization.

\footnotetext{
${ }^{9}$ According to data provided by the National German labor market research institution, the total number of employees (without trainees, self-employed workers and public service) rose during the period 1996-2002 from 46,295 to 60,496 in the field of publishing, from 25,273 to 32,938 in the field of arts/graphic design and from 290,195 to 447,935 in the field of data management specialists (www.abis.iab.de/bisds/data/seite_821_BO:a.htm, accessed: 18.11.2003).

${ }^{10}$ From 1996-2002, the percentage of female workers in publishing rose only slightly from 37.8 percent to 41.2 percent and from 50.7 percent to 51.5 percent in the field of arts/graphic design (source: www.abis.iab.de/bisds/data/seite_821_BO:a.htm, accessed: 18.11.2003).
} 
In contrast, the growing workforce in IT-related occupations such as software development raised no major problems until the 2001 crisis due to labor shortages. Contrary to expectations, the high demand for qualified workers in this sector did not lead to a rise in the low numbers of female workers. ${ }^{11}$ Experts report that in this professional field, freelancing is mostly seen as a career opportunity for experienced workers, providing more challenges and better income than work as an employee. Employers regard IT-freelancers as a flexible labor reserve that complements the existing in-house workforce. However, employers assume that freelancers are less loyal to the firm, so they attempt to control their output by making them work on-site (Paul 2003). As opposed to freelance journalists and designers, software freelancers are not necessarily full-service providers. Often they are integrated into a customer's in-house project team as project managers, IT counselors or programmers. In the IT industry, job agencies that operate on the internet offer services similar to temporary workers' agencies, providing contacts between clients and freelancers for a fee that the freelancer pays. $(\leftarrow$ p. 52)

\section{Professional Associations}

In all three groups, professional associations play an important role in collective selfregulation. However, their bargaining power and their strategies differ considerably. In journalism and design, centralized professional organizations have developed innovative strategies to promote the interests of freelancers (Betzelt and Gottschall 2004), while the professional organizations that serve IT freelancers are diverse and have little bargaining power.

Professional associations in the fields of journalism and design offer further training opportunities and try to set quality and price standards as a strategy to cope with deteriorating market conditions. The most important professional organization in the field of journalism cooperates closely with the service sector trade union; its membership data show that it covers roughly 47 percent of Germany's full-time journalists (Gottschall and Betzelt 2004: 8). The association combines elements of professional and trade-unionist strategies. At least for daily newspapers and the public media, fees are fixed by line or minute of broadcasting in accordance with a collective agreement with the employers' organization. This agreement also covers some social benefits, such as paid holidays and maternity leave. On the other hand, the private media sector is dominated by individual agreements (see Bleses in this volume). However, for freelance print journalists the collective agreement rather establishes a minimum wage, as print media pay considerably less than employers in television and public relations.

In the field of design, professional associations are more diverse and less highly organized. Taken together, the three largest organizations have about 4,400 members, covering roughly 6 percent of the graphic designers listed in the representative German Mikrozensus panel (Gottschall and Betzelt 2004: 8). Today's most important professional organization offers services specifically tailored for freelancers and tries to implement quality and price

\footnotetext{
${ }^{11}$ Dostal (2002: 201) calculates the percentage of female workers in the computer occupations at 16.8 percent. According to another source (www.abis.iab.de/bisds/data/seite_821_BO:a.htm, accessed: 18.11.2003), the percentage of female employees in the field of data management was 21.4 percent in 1996 , and 20.3 percent in 2002 .
} 
standards. However, given the cut-throat price competition, these price standards are generally regarded as unrealistic by our interview partners.

Professional organizations for freelance software developers are even more diverse, which makes it difficult to assess their degree of organization. Freelancers in this industry can apply for membership in one of the large industry associations that dominate the debates on standards $(\leftarrow \mathbf{p . ~ 5 3})$ for qualification and the quality of work in this field. They also can organize through the German computer science association that runs an informal working group for IT freelancers, focusing on general information on political and legal developments and providing a sense of community among this group. They may also apply for membership in a number of small organizations which focus on highly specialized professional training courses to keep members up to date with changes in this fast moving industry. ${ }^{12}$ Against the background of a relatively stable market where prices are still high in spite of a slight decrease after 2001, market transparency is provided by virtual market places (e.g., gulp.de or freelance.com) that publish income data.

\section{Income Structure}

These many differences in the labor markets and in the strategies of professional associations lead to very different income situations for the three groups we studied. The income of freelancers in the media industry generally covers a spectrum from low incomes for most workers to high incomes for a small professional elite (Betzelt and Gottschall 2004: 261). ${ }^{13}$ For freelance journalists and designers, our survey data confirmed this finding (for details, see Henninger 2004). For software freelancers, however, available data ${ }^{14}$ as well as our own findings indicate higher incomes. Available income data for freelance journalists and software developers point to lower incomes in Eastern Germany. This finding corre- $(\leftarrow \mathbf{p . ~ 5 4})$ sponds to the concentration of the industry in a number of urban centers in the old German states (Länder); except for the Berlin/ Potsdam area, the new Länder have not yet been able to develop similar clusters (Krätke 2002).

\section{Consequences of the Hybrid Type of Regulation}

As a result of the hybrid type of regulation in this field, freelancers in the German media industry are less protected against market risks than either standard employees or members of the classic professions. For self-employed media workers, market risks are individualized, combined with a weak bargaining position in the market. Moreover, a considerable number of freelancers in this industry cluster in the lower income brackets and have no resources to

\footnotetext{
${ }^{12}$ According to experts, the most important of these organizations include the Bundesverband Selbstständige in der Informatik (360 members in 2003) and the Gesellschaft für Projektmanagement (3000 members in 2004) which also organizes project managers and consultants from other industries.

${ }^{13}$ Representative data are available only for freelance journalists: according to Grass (1998: 70), at the end of the $1990 \mathrm{~s}, 29.7$ percent of freelance journalists had a monthly income of less than 2000 DM (approx. 1000 Euro) before taxes, 43.7 percent had an income between 2000 and 8000 DM (ca. 1000-4000 Euro), while only 5.8 percent of respondents had a monthly income of over 8000 DM (ca. 4000 Euro).

${ }^{14}$ In 2003, the average annual net revenue of all software freelancers registered at the internet market place, gulp.de, was 85,922 Euro. 8.37 percent had an annual net revenue from 0-2000 Euro, 33.75 percent reached 2000-80,000 Euro, and 57.88 percent more than 80,000 Euro. (our calculations based on: www.gulp.de/cgigulp/trendneu/.exe/MONEYFORMDLL, accessed: 03.03.2004).
} 
cushion periods without an income. Given their insecure position and market pressures, many of them may find that the flexibility of self-employment coincides with a dissolution of the boundaries between work and life.

Our analysis points to considerable differences between the professional labor markets in the German media industry. Specific trends in the professional labor markets result from a divergent demand and supply situation as well as from differences in the degree of organization and in the strategies of the professional organizations, resulting in different income situations for freelancers from the three professional groups. While the income of freelance software developers is higher, on average, freelance journalists and designers often have relatively low incomes, despite their high qualifications. Thus many journalists and designers do not have the family wage that is an important pre-requisite for the malebreadwinner model. Consequently, the prevalence of dual-earner arrangements may vary across the occupational groups that are covered in our sample.

\section{Work-Life Arrangements among Freelancers}

Considerable controversy colors the debate about the consequences that the flexibility of freelance work has on individual work-life arrangements. Some authors argue that the increased flexibility of freelance work makes it easier to combine paid work and other activities, in $(\leftarrow$ p. 55) particular childcare (Gold and Fraser 2002), while others believe, instead, that the flexibility of freelance work fosters a single life style (Jurczyk and Voß 2000: 155). However, the existing representative data we consulted indicate that freelance work does not coincide with a predominance of a certain type of household. In fact, no major differences exist between self-employed workers in general and employees, as Leicht and Lauxen-Ulbrich (2002) demonstrate using data from the German Mikrozensus panel. That is, approximately 20 percent of both freelancers and employees are single, while approximately 40 percent live in a partnership without children, and roughly one third live in a partnership with children.

The results from our questionnaire survey among freelancers in the media industry underline the general trend towards 'normality', but show a somewhat different picture. Compared to the data provided by Leicht and Lauxen-Ulbrich (2002), in our sample the percentage of freelancers who live in a partnership without children is higher for all professional groups (average: 55 percent), while singles are slightly underrepresented (average: 13 percent). Partnerships with children still make up about one third of respondents. Two exceptions stand out from this pattern: female designers rarely live in a partnership with children (12 percent), and for male software developers, this is the most important type of household (53 percent) (for all data, see Henninger 2004). These differences are not due to the age of respondents, as compared to available representative data (Dostal 2002: 201), middle-aged freelancers are overrepresented in our survey sample in all three professional groups. In any case the statistical data do not reveal how freelancers in different types of households combine work and other activities on a day to day basis, and how freelancing affects the organization of household duties and care work. Here, our interview data provide additional information. ${ }^{15}$

\footnotetext{
${ }^{15}$ All quotations in the following part are taken from our interview sample and were translated into English from the German original.
} 
Consistent with their counterparts in the public statistics, roughly three quarters of our interview sample consists of freelancers living in partnerships, and approximately one third of the interviewees have children up to age 18 living at home. We deliberately included freelanc$(\leftarrow$ p. 56) ers with low, middle and high income levels to cover the broad income spectrum. Because we assumed that difficulties combining freelancing with a partnership and raising a family would be most salient for middle-aged interview partners, we arranged for middleaged freelancers (35-50 years old) to make up approximately two-thirds of the sample. Meanwhile, the youngest (up to 35) and oldest cohorts of freelancers (50 or older) each make up about one sixth. Because a key aim of the study was to analyze possible gender effects, our interview sample consisted of approximately equal numbers of men and women. In the following section, we present selected results from our interviews, focusing first on individual work-life arrangements to assess how widely the freelancers in this industry dissolve the boundaries between their work and private life. As partnerships provide the possibility to develop mutually dependent work-life arrangements, in a second step we concentrate on the gender arrangements among those interviewees who live in a partnership, allowing us to explore whether and how freelancing is accompanied by changing gender arrangements.

\section{Individual Work-Life Arrangements}

The patterns of work and life that we found in our sample were categorized as balanced or as job-focused according to the interview partners' individual preferences for work-related vs. non work-related activities and their reported time allocation. As we assume that individual work-life arrangements are influenced by the type of household and by gender specific norms for men and women, we present the data according to these categories.

A first result is that the single workers in our sample are distributed evenly between balanced and job-focused arrangements, while the majority of interviewees living in partnerships, with or without children, cluster in the category of job-focused arrangements. The men and women in our sample show a similar distribution on balanced and job-focused arrangements - a striking finding indicating that male and female freelancers develop similar patterns of work and life.

Given the hypothesis that freelancers dis-enclose, or blur the boundaries between, work and life, it is interesting that one third of our interview partners can be categorized as balanced. They share their priorities among activities that are and are not work-related, even if this sometimes $(\leftarrow$ p. 57) means forsaking additional income possibilities by rejecting job offers. Striving to balance work and private life means they have more time available to devote to children or to other interests. Balanced arrangements result mostly from personal choice, while in the lower income brackets constraints also play a role. Four of our interview partners point to the importance of leisure time for their recreation and creativity, while seven others regard their job as equally important as raising children or spending time with a partner who has a severe illness. One older journalist now has a balanced arrangement because of his longterm unemployment. He is working part-time as a freelancer to supplement his unemployment benefits.

Nevertheless, two thirds of our sample can be categorized as job-focused. This group includes singles as well as interviewees living in a partnership, among them a number of parents. Placing a high priority on the job means not having much leisure time and postponing other 
wishes and interests. Two female interview partners say they have refrained from having children, either due to a low and insecure income or because an interesting and demanding job life seemed to leave no time for this.

While the interviewees in this group placed a high priority on their jobs, a number of those who can be categorized as job-focused still draw a clear line between work and life. Strategies to separate work and life include free evenings or weekends, opting for an office outside the house, and deliberately separating job-related and private contacts. Moreover, drawing boundaries between work and life allows them to satisfy other, non work-related needs and interests, for example a hobby that has nothing to do with their work. At the same time, some interviewees see this limitation as crucial to keeping them employable over the long term. As a male designer explained:

I need to regenerate myself, otherwise some day I will no longer be able to work any more. I have to keep myself in good shape and in a good mood. And I have to take care that I spend my leisure time on reasonable activities, such as sports.

Our sample also provides examples of a dis-enclosure of work and life, which is blurring the boundaries between the two. Six interview partners in the upper income brackets in all three professions were highly identified $(\leftarrow$ p. 58) with their job and had extensive work hours. Generally, they feel their highly interesting and rewarding jobs compensate for their heavy time commitment. In the lower income bracket we also found evidence of a market-driven dis-enclosure of work and life, a phenomenon that affected one of the newcomers as well as two experienced freelancers, as growing older in a fast-moving market seems to increase the market risks. Because a low income provides no cushion for slack times, these interviewees experience the negative consequences of the economic insecurity connected to their status as freelancers. They report working long hours when a job does come in, followed by periods of unwanted idleness.

Tendencies to dis-enclose, or dissolve boundaries between, work and life seem to be related to a specific phase of life and may change over time. For example, two interviewees who are young and at the beginning of their career see their high commitment to work as temporarily necessary while they build up their businesses. Others report how their priorities changed over time, for a range of reasons. Two realized that the quality of their work suffers when they are over-worked, one wished to spend more time with a child, two said their high job involvement had led to conflicts - and separations - in their partnerships, and two felt they were feeling more need to rest as they grew older.

\section{Gender Arrangements among Interviewees Living with Partners}

To explore whether and how freelancing is accompanied by changing gender arrangements, in the next section we focus on interview partners who live in a partnership. To describe the complex work-life arrangements of couples, we draw on a typology developed by Rüling, Kassner and Grottian (2004) that links individual priorities of work and private life with patterns of gender arrangements in a partnership. In an empirical study on young families, the authors distinguish different combinations of individual work-life arrangements: in partnerships they label as 'structurally equal', both partners are either putting a focus on work or family or on a balanced combination of both. On the other hand, in partnerships labeled as 'structurally specialized', the two partners have different priorities, resulting either in a 
traditional male-breadwinner pattern or in reversed gender roles with a female-breadwinner and a male care worker. $(\leftarrow$ p. 59)

To classify our interview partners using this typology, we relied on the information they provided on their individual preferences for activities that were or were not work-related, as well as their reported time allocation and share of household income. Partnerships where both partners share the same priorities were categorized as balanced, as job focused/different jobs or as job-focused/production team. We identified the latter category as a special form of a structurally equal partnership among freelancers. This pattern is characterized by mutual support in the making of a (collective) product, and housework is organized following the demands of the job. Partnerships where one partner is job-focused while the other tries to balance work and life were characterized as structurally different and are listed as traditional (male-breadwinner/ female part-time worker and caregiver) or as reversed gender arrangements (female-breadwinner/male part-time worker and caregiver). ${ }^{16}$

Four interview partners who could not be categorized according to this typology have been left out of the following analysis, as their partnerships showed no clear pattern of a shared work-life arrangement. We observed this in two new partnerships, where stable patterns still have to be established, and two others where a common future perspective is

Table 1. Individual work-life arrangements among interviewees $(\mathrm{N}=39)^{*}$.

\begin{tabular}{|c|c|c|c|}
\hline \multirow[t]{2}{*}{$\operatorname{sex}$} & \multirow[t]{2}{*}{ Type of Household } & \multicolumn{2}{|c|}{ Individual work-life arrangement } \\
\hline & & balanced & job-focused \\
\hline \multirow[t]{4}{*}{ women } & Single without children & 1 & 1 \\
\hline & Single with children & 1 & - \\
\hline & Partnership without children & 1 & 6 \\
\hline & Partnership with children & 2 & 6 \\
\hline \multirow[t]{4}{*}{ men } & Single without children & 2 & 1 \\
\hline & Single with children & - & - \\
\hline & Partnership without children & 2 & 10 \\
\hline & Partnership with children & 3 & 3 \\
\hline
\end{tabular}

* Children are listed up to the age of 18 when living in the same household.

\section{$(\leftarrow$ p. 60)}

unclear, due either to the illness of a partner or a pending separation. Especially for interview partners with a low income who place a high priority on their job, this led to conflicts in their partnerships. As one male designer put it: "if you live for your job like this, there always will be problems". 17

To explore the possible influence of profession, gender, and the existence of children on freelancers' gender arrangements, we now present data from the remaining 29 interviews with freelancers living in a partnership following these categories.

\footnotetext{
${ }^{16}$ The family-focused pattern described by Rüling, Kassner and Grottian (2004) was not to be found, probably due to the pre-selection of interviewees (active freelancers recruited through professional associations).

${ }^{17}$ All interviewees categorized as living in an open arrangement are freelance designers. It remains unclear from our data whether this results from specific constellations in interviewees' partnerships or from their professional background.
} 


\section{Gender Arrangements among Male and Female Interviewees}

First, our results reveal an equal distribution of men and women into structurally equal and structurally specialized partnerships. Among those living in structurally specialized arrangements, an even number of interviewees live in a traditional and in a reversed gender arrangement (see Table 2).

Table 2. Gender arrangements among male and female interviewees.

\begin{tabular}{l|ccc|cc}
\hline \multirow{2}{*}{$\begin{array}{r}\text { Gender } \\
\text { arrange- } \\
\text { ment }\end{array}$} & \multicolumn{3}{|c|}{ structurally equal } & \multicolumn{2}{c}{ structurally specialized } \\
\cline { 2 - 6 } arrangements & $\begin{array}{c}\text { job-focused/ } \\
\text { different jobs }\end{array}$ & $\begin{array}{c}\text { job-focused/ } \\
\text { production } \\
\text { team }\end{array}$ & $\begin{array}{c}\text { traditional } \\
\text { arrangement }\end{array}$ & $\begin{array}{c}\text { reversed } \\
\text { gender } \\
\text { arrangement }\end{array}$ \\
\hline men & 2 & 2 & 6 & 3 & 2 \\
women & 1 & 5 & 3 & 2 & 3 \\
\hline
\end{tabular}

As might be expected from the different cultural norms in Eastern and Western Germany, most interview partners from the former GDR who are now living in a partnership fall into the category of a job-focused partnership. ${ }^{18}$ For them, the model of a dual-earner couple still serves $(\leftarrow$ p. 61) as a point of reference, with both partners working full time. The three whose children are now adults had used institutionalized childcare facilities to combine work and family when those children were small. The partners divide up household duties, with women responsible for a larger part. On the other hand, we found that interviewees from Western Germany were spread more evenly over the different types of partnerships. However, this result must be interpreted with care, as our findings indicate that living together with smaller children is the most decisive factor influencing gender arrangements among our interviewees: ${ }^{19}$ Interview partners who live in partnerships without children cluster in structurally equal, job-focused arrangements (13 out of 14), while nine out of 14 interviewees in partnerships with children under 18 cluster in specialized arrangements (see Table 3 ).

\footnotetext{
${ }^{18}$ Eight of our interview partners grew up in the GDR. Two of them are single; the other six live in a partnership. One of them is regarded as an example of an open arrangement, see above.

${ }^{19}$ Due to limits of our sample, we are not able to discern whether living in a partnership with children results in different gender arrangements in Eastern and Western Germany, as only one interview partner from East Germany who was living in a partnership had children under 18.
} 
Table 3. Gender arrangements in partnerships with and without children.

\begin{tabular}{l|ccc|cc}
\hline $\begin{array}{r}\text { Gender } \\
\text { arrange- } \\
\text { ment }\end{array}$ & \multicolumn{3}{|c|}{ structurally equal } & \multicolumn{2}{c}{ structurally specialized } \\
\cline { 2 - 6 } $\begin{array}{c}\text { Type of } \\
\text { household }\end{array}$ & balanced & $\begin{array}{c}\text { job-focused/ } \\
\text { arrangements }\end{array}$ & $\begin{array}{c}\text { job-focused/ } \\
\text { production } \\
\text { team }\end{array}$ & $\begin{array}{c}\text { traditional } \\
\text { arrangement }\end{array}$ & $\begin{array}{c}\text { reversed } \\
\text { gender } \\
\text { arrangement }\end{array}$ \\
\hline Partnerships & 2 & 5 & 8 & 1 & - \\
with children & 1 & 2 & 1 & 4 & 5 \\
\hline
\end{tabular}

Only three interviewees live in structurally equal partnerships in which both partners try to find a balance between their job and their private life. While other interviewees prefer balanced arrangements for different reasons (as described above), one male journalist shares childcare and housework with his wife who works part-time. He works mornings and evening hours so he can spend the afternoon with his child. The example $(\leftarrow \mathbf{p . ~ 6 2})$ of one female journalist shows how a balanced arrangement can potentially be destabilized: while the couple both worked part-time and shared care responsibilities after the first child was born, they had returned to a male-breadwinner model after their second child was born.

\section{Gender Arrangements in Partnerships with and without Children}

Here, not very surprisingly, 13 of our 15 interview partners without children cluster in structurally equal partnerships where both partners focus on their job (see Table 3). These interviewees' partners either work in different jobs, or both are working freelance, cooperating on a production team. In five cases, both partners identify very strongly with their job. For them, living and working together as a production team coincides with a blurring of work and private life. Three other interviewees in this category still draw a line between work and private life and find time for leisure or for their hobbies in spite of a strong job orientation.

While most interview partners living in a job-focused partnership have no small children, three people in this category do. Supported by a high family income, two female journalists rely on private services for childcare. One, who has a 9-month old baby, shares childcare duties with her partner. The couple has two nannies, and a friend helps out regularly with childcare. A male software freelancer, whose youngest child is now 13, lived in a traditional arrangement when his children were small and he still had a high income. After the children went to school, his wife started her own business offering office and software services; it has now become the backbone of the family economy, as he has difficulties finding new customers since he finished his last project 18 months ago. 
By contrast, with one exception, ${ }^{20}$ all interviewees in structurally specialized partnerships are parents. A striking result here is that within this group we find a nearly equal distribution of traditional and reversed gender arrangements with no significant gender effects (see Table 2).

While women living in specialized arrangements often point to some ambivalence, the men seem to be comfortable with this pattern. After $(\leftarrow \mathbf{p . ~ 6 3})$ the birth of a child, two female journalists lived in traditional arrangements, working part-time and assuming the larger part of household and care work while their partner worked full time in a job earning a family income. They saw this arrangement as a temporary one that would let them care for small children. Both women pointed to the ambivalence that the flexibility of working freelance has for them. On the one hand, working part-time gives them more resources to combine work and family. However, this same flexibility let their spouses assign them more care work, resulting in conflicts in their partnerships. Looking back to the time when her daughter was small, one journalist whose partner worked full-time as an employee remembers:

I always had to be the more flexible one. And this resulted in more constraints in the organization of my day. I mean, if someone had to be somewhere at 3:30 [to pick up the child], then it had to be me. Or I had to organize that someone else was there.

By contrast, among the three men in our sample who lived in traditional arrangements, houseand care work were not an issue. The males in family relationships did not have the additional burden of social responsibility for children or other domestic chores to balance with their professional lives. However, all these interviewees stated that this arrangement could change due to financial constraints: in periods of low or no income, they would need an additional income. Thus, apart from the fact that it creates different pressures on men and women, the traditional arrangement does not seem to be a lifelong option.

A surprising finding was the existence of patterns based on reversed gender roles with a female-breadwinner and a male part-timer taking over a larger part of household and care work. Here again, the women in this arrangement tend to feel some pressure while the male interviewees see it as a win-win situation. Three women had arrangements based on reversed gender roles. Two of them said they felt constantly under pressure, never finding enough time for the children and still feeling responsible for the organization of the household, among them a journalist with a top-level income and an 8-year-old son. She values her partner's contribution to childcare and housework. In addition, the couple employs a nanny, several babysitters, and a cleaning woman. $(\leftarrow$ p. 64) However, she still maintains the responsibility of assigning the tasks: "instead, seeing what has to be done or that something has to be done, this is my task."

By contrast, the two male part-timers in reversed arrangements both consider themselves "lucky" or even "privileged". They describe this arrangement as the result of financial constraints as well as individual preferences. Both have partners who work in full-time jobs that pay well, while their own income was either low or irregular when the first child was born. Not being responsible for the family income allows them to take on only the jobs that they like. Thus, while mothers living in structurally specialized arrangements continue to

\footnotetext{
${ }^{20}$ One designer actually lives in a partnership with a gender-specific division of domestic duties. However, he is happy not to be under pressure to support a family with his low income, as his wife is unable to work and collects a pension.
} 
struggle with expectations arising from a traditional gender role, for men, this arrangement seems instead to be a result of personal choice and can be changed, if necessary.

\section{Gender Arrangements in Different Professional Groups}

Finally, we turn to gender arrangements in different professional groups. Here, we see a difference between designers and journalists on the one hand and software freelancers on the other (Table 4).

Table 4. Gender arrangements in different professional groups.

\begin{tabular}{l|ccc|cc}
\hline $\begin{array}{r}\text { Gender } \\
\text { arrange- } \\
\text { ment }\end{array}$ & \multicolumn{3}{|c|}{ structurally equal } & \multicolumn{2}{c}{ structurally specialized } \\
\cline { 2 - 6 } $\begin{array}{c}\text { Type of } \\
\text { household }\end{array}$ & balanced & $\begin{array}{c}\text { job-focused/ } \\
\text { different jobs }\end{array}$ & $\begin{array}{c}\text { job-focused/ } \\
\text { production } \\
\text { team }\end{array}$ & $\begin{array}{c}\text { traditional } \\
\text { arrangement }\end{array}$ & $\begin{array}{c}\text { reversed } \\
\text { gender } \\
\text { arrangement }\end{array}$ \\
\hline $\begin{array}{l}\text { Designers } \\
\text { Journalists }\end{array}$ & 2 & 1 & 3 & 1 & 1 \\
$\begin{array}{l}\text { Software } \\
\text { Developers }\end{array}$ & - & 4 & 4 & 2 & 2 \\
\hline
\end{tabular}

Among the designers and journalists in our sample, about two thirds cluster in structurally equal arrangements, while software freelancers are evenly split among structurally equal and specialized arrangements. We could identify no balanced arrangements among the software developers $(\leftarrow \mathbf{p . ~ 6 5})$ in our sample. Concerning the opportunity to earn a family income, it is interesting that all the software developers who live in structurally specialized arrangements are the main breadwinners in their family. In contrast, for most of the journalists and designers, what made a specialized arrangement possible was the family income their partners earned.

\section{Divergent Patterns of Work and Life}

Returning to the question of a dis-enclosure of work and life, the work-life arrangements of the freelancers in our sample provide no empirical evidence for a general trend towards dissolving borders. One third of our interviewees live in balanced arrangements, placing the same priority on their work as on other aspects of life. Among those living in job-focused arrangements, only a minority show characteristics of a clear dis-enclosure, while others still draw a sharp line between work and life. Moreover, work-life arrangements can change over time, and periods of de-limitation may be followed by attempts to separate both spheres more clearly.

The gender differences in our sample turned out to be minimal: men and women spread evenly on job-focused and balanced arrangements as well as on the different types of gender arrangements in partnerships. As is the case for individual work-life arrangements, gender 
arrangements among interviewees living in a partnership may also change over time, e.g., after a child is born or one partner's job situation changes.

The gender arrangements in our sample are diverse. Living together with children turned out to be the most decisive factor in opting for a specific arrangement: interview partners who live in partnerships without children cluster in structurally equal, job-focused arrangements, while those interviewees in partnerships with children cluster in specialized arrangements.

These findings indicate a move towards less traditional gender arrangements among freelancers in the German media industry. Among freelancers living in a partnership, dualearner patterns are widespread, indicating a departure from the more traditional malebreadwinner model. At the same time, the dual-earner model is not emerging as the only pattern in gender arrangements. One third of those in this group opt for structurally specialized arrangements. It is within these arrangements that we can observe a further change: among this group, part- $(\leftarrow \mathbf{p . ~ 6 5})$ nerships based on traditional as well as on reversed gender roles are evenly represented. Thus, in our sample, gender arrangements based on reversed gender roles are emerging as a less traditional pattern, with men taking over care responsibilities. On the one hand, this arrangement fits with the German institutional setting, characterized by a limited provision of (affordable) childcare and by half-day schooling, that promotes such a specialization; on the other hand, it contradicts the roles that gendered norms would predict for men and women.

Male and female interviewees differed in their evaluation of these structurally different arrangements, where women point to the ambivalence of these arrangements, while for men this seems to be a win-win situation. Thus, although gender arrangements have become modernized among freelancers in the media industry, the traditional malebreadwinner/female-caregiver pattern still casts its shadow on gender relations among this group.

\section{Towards Global Patterns of Work and Life?}

Considering our results in the light of international research, we find they only partially support the notion of a globalized pattern of work and life in the media industry. Without doubt, self-employed media workers in Western countries are all exposed to highly competitive markets. Available data on UK and US media workers indicate working conditions similar to those for freelance knowledge workers in Germany: a tendency to overlong working hours, a polarization of income and a dominance of informal labor market governance (Gill 2002; Batt and others 2001). Gender inequality - in terms of female underrepresentation in the higher income brackets and exclusion from male dominated networks which are crucial for market integration - might be more pronounced in the liberal market economies than in Germany. At the same time, however, the mere fact of a high proportion of women in this field in all countries indicates a convergence.

However, if we look at strategies for dealing with high market risks the national context still seems to make a difference. Media workers in the UK, and especially in the US, lack professional organizations, eligibility to employment rights and social security provision; thus media $(\leftarrow$ p. 67) freelancers are becoming aligned with other vulnerable groups in these uncoordinated market economies. German media freelancers suffer instead from an 'inbetween status': they are not well secured dependent employees but neither are they in the 
position of the classical professions that can take advantage of market monopolies. Still, to some extent those engaged in this hybrid type of employment can profit from the more coordinated structure of labor relations and market governance in Germany by availing themselves of the minimum social security provisions for special occupational groups and by evolving new collective bodies. In fact, the workers themselves turn to hybrid strategies, in that they rely on collective practices without questioning that their individual success in the market forms the basis of freelance work (Gottschall and Kroos 2007).

Looking at these workers' work-life and gender arrangements we see both convergence and divergence with trends in the US and UK. The predominance of dual-career partnerships in the field of highly qualified workers seems to be a general trend as well as the 'neo-liberal' or postmodern re-emergence of the family as an important 'risk hedge' to cover for income loss in times of slack employment or of illness, as Carnoy (2000) argues for the US. However, in our study, the gender relations inside the family differ from the dual-earner model of the US, especially for parents, who cluster in structurally specialized partnerships, with one of the partners bearing the main responsibility for childcare and housework. Thus, the German institutional setting still "force[s] parents' life courses into their program of a mutually referential arrangement of life" (Krüger 2003: 42), though in a less gendered way than in the past. At the same time the high prevalence of job-focused life styles might indicate that workers in knowledge-intensive industries indeed show patterns of work and life beyond the industrial model, leaving open the question of who is bearing the risks and costs.

\section{References}

Batt, Rosemary and others. 2001. Net Working. Working Patterns and Workforce Policies for the New Media Industry. Washington, DC: Economic Policy Institute.

Baumann, Arne. 2002. "Informal Labour Market Governance: The Case of the British and German Media Production Industries”. Work, Employment and Society 16 (1): 27-46.

\section{$(\leftarrow$ p. 68)}

Betzelt, Sigrid and Gottschall, Karin. 2004. Publishing and the New Media Professions as Forerunners of Pioneer Work and Life Patterns. In Janet Z. Giele and Elke Holst, eds., Changing Life Patterns in Western Industrial Societies. London: Elsevier: 257-280.

Carnoy, Martin. 2000. Sustaining the New Economy. Work, Family, and the Community in the Information Age. Cambridge, MA./ London: Harvard University Press.

Casper, Steven, Mark Lehrer and David Soskice. 1999. "Can High-Technology Industries Prosper in Germany? Institutional Frameworks and the Evolution of the German Software and Biotechnology Industries", Industry and Innovation 6 (1): 5-24.

Crompton, Rosemary. 2001. "Gender Restructuring, Employment, and Caring”. Social Politics 8 (3): 266-291.

Crouch, Colin and Wolfgang Streeck, eds. 1997. Political Economy of Modern Capitalism: Mapping Convergence and Diversity. London: Sage. 
Dex, Shirley and others. 2000. "Freelance Workers and Contract Uncertainty: The Effects of Contractual Changes in the Television Industry". Work, Employment and Society 14 (2): 283305 .

Dingeldey, Irene. 2001. "European Tax Systems and their Impact on Family Employment Patterns”. International Social Policy 30 (4): 653-672.

Dölling, Irene. 1998. Structure and Eigensinn: Transformation Processes and Continuities of East German Women. In Patricia J. Smith, ed., After the Wall: Eastern Germany since 1989. Boulder, CO: Westview Press: 183-201.

Dostal, Werner. 2002. Berufe im Wandel: Anforderungen an die Entwicklung von Berufen im Kultur- und Medienbereich aufgrund des Einsatzes neuer Technolgien. In Olaf Zimmermann and Gabriele Schulz, eds., Kulturelle Bildung in der Wissensgesellschaft - Zukunft der Kulturberufe. Berlin/Bonn: Deutscher Kulturrat e.V.: 181-236.

Fraser, Janet and Michael Gold. 2001. "'Portfolio Workers': Autonomy and Control amongst Freelance Translators". Work, Employment and Society 15 (4): 679-697.

Gill, Rosalind. 2002. "Cool, Creative and Egalitarian? Exploring Gender in Project-Based New Media Work in Europe”. Information, Communication and Society 5 (1): 70-89.

Gold, Michael and Janet Fraser. 2002. "Managing Self-Management: Successful Transitions to Portfolio Careers". Work, Employment and Society 16 (4): 579-597.

Gottschall, Karin. 2002. New Forms of Employment in Germany: Labor Market Regulation and its Gendered Implications. Wayne State University Occasional Paper Series No. 8, March 2002. Detroit, MI: Wayne State University.

Gottschall, Karin and Sigrid Betzelt. 2004. Abschlussbericht DFG-Projekt GO 969/1-2 "Kulturberufe". Bremen (unpublished research report).

Gottschall, Karin and Daniela Kroos. 2007. Self-Employment in Comparative Perspective. General Trends and the Case of New Media. In Sylvia Walby and others, eds., Gendering the Knowledge Economy: Comparative Perspectives. Houndmills/Basingstoke: Palgrave Macmillan: 163-187.

Gottschall, Karin and G. Günter Voß, eds. 2003. Entgrenzung von Arbeit und Leben. Zum Wandel der Beziehung von Erwerbstätigkeit und Privatsphäre im Alltag. München und Mehring: Rainer Hampp Verlag.

Granger, Bill, John Stanworth and Celia Stanworth. 1995. "Self-Employment Career Dynamics: The Case of 'Unemployment Push' in UK Book Publishing”. Work, Employment and Society 9 (3): 499-516. (广 p. 69)

Grass, Bernd. 1998. "Arbeitsbedingungen freier Journalisten. Bericht zu einer Umfrage unter Mitgliedern des DJV”. Journalist 11: 65-80.

Grey, Susan and Geraldine Healy. 2004. "Woman and IT Contracting Work - a Testing Process". New Technology, Work and Employment 19 (1): 30-42.

Haak, Carroll and Günter Schmid. 1999. Arbeitsmärkte für Künstler und PublizistenModelle einer zukünftigen Arbeitswelt? Wissenschaftszentrum Berlin für Sozialforschung, Discussion Paper P99-506. Berlin: Wissenschaftszentrum Berlin für Sozialforschung. 
Hall, Peter A. and David Soskice, eds. 2001. Varieties of Capitalism. The Institutional Foundations of Comparative Advantage. New York: Oxford University Press.

Handy, Charles. 1994. The Empty Raincoat. Making Sense of the Future. London: Hutchinson.

Henninger, Annette. 2004. Freelancer in den Neuen Medien: Jenseits standardisierter Muster von Arbeit und Leben? In Heike Kahlert and Claudia Kajatin, eds., Arbeit und Vernetzung im Informationszeitalter. Wie neue Technologien die Geschlechterverhältnisse verändern? Frankfurt a.M./New York: Campus: 164-181.

Henninger, Annette and Ulrike Papouschek. 2006. "Entgrenzte Erwerbsarbeit als Chance oder Risiko? Mobile Pflege und die Medien- und Kulturindustrie im Vergleich". Berliner Journal 16 (2): 189-209.

Jurczyk, Karin and Maria S. Rerrich. 1993. Lebensführung weiblich - Lebensführung männlich. Macht dieser Unterschied heute noch Sinn. In Karin Jurczyk and Maria S. Rerrich, eds., Die Arbeit des Alltags. Beiträge zu einer Soziologie der alltäglichen Lebensführung. Freiburg im Breisgau: Lambertus: 279-309.

Jurczyk, Karin and G. Günter Voß. 2000. Entgrenzte Arbeitszeit - Reflexive Alltagszeit. In Eckart Hildebrandt, ed., Reflexive Lebensführung. Zu den sozialökologischen Folgen flexibler Arbeit. Berlin: edition sigma: 151-205.

Kotamraju, Nalini P. 2002. "Keeping Up: Web Design Skill and the Reinvented Worker". Information, Communication and Society 5 (1): 1-26.

Krätke, Stefan. 2002. Global Media Cities in a Worldwide Urban Network. GAWC (Globalization and World Cities Study Group and Network) Bulletin 80, www.lboro.ac. uk/gawc/br/rb80.html (accessed: 17.09.2002): 1-23.

Krüger, Helga. 2003. The Life-Course Regime. Ambiguities Between Interrelatedness and Individualization. In Walter R. Heinz and Victor W. Marshall, eds., Social Dynamics of the Life Course. Transitions, Institutions, and Interrelations. New York: Aldine de Gruyter: 3356.

Lane, Christel, Margaret Potton and Wolfgang Littek. 2000. The Professions Between State and Market. A Cross-National Study of Convergence and Divergence. ECSR Working Paper 189. Cambridge: University of Cambridge.

Leicht, Rene and Maria Lauxen-Ulbricht. 2002. Soloselbständige Frauen in Deutschland: Entwicklung, wirtschaftliche Orientierung und Ressourcen. Forschungsprojekt "Gründerinnen in Deutschland" im Auftrag des Bundesministeriums für Bildung und Forschung. DownloadPaper Nr. 3/2002, http://www.ifm.uni-mannheim.de (accessed: 05.11.2002). Mannheim: Institut für Mittelstandsforschung, Universität Mannheim.

Leisering, Lutz. 2003. Government and the Life Course. In J.T. Mortimer and M.J. Shanahan, eds., Handbook of the Life Course. New York and others: Kluwer: 205-225.

\section{$(\leftarrow$ p. 70)}

Lewis, Jane and Ilona Ostner. 1994. Gender and the Evolution of European Social Policy. ZeS Working Paper 4. Bremen: Centre for Social Policy Research, University of Bremen. Löffelholz, Martin and others. 2003. "Onlinejournalisten in Deutschland. Zentrale Befunde 
der ersten Repräsentativbefragung deutscher Online-Journalisten”. Media Perspektiven 10: 477-486.

Paul, Gerd. 2003. Firms of the New Economy and Their Workers Revisited: Back to Normality? Paper presented at the 15th Annual Meeting on Socio-Economics. LEST, Aix-enProvence, 26.-28.06.2003. www.sase.org/conf2003/papers/papers. html (accessed: 19.05.04).

Perrons, Diane. 2004. Equity and Representation in the New Economy. In John Kelly and Paul Willman, eds., Union Organization and Activity. London: Routledge.

2005. Gender equality and the work-life balance: policies and practices in the new economy. In Bram Peper, Anneke van Doorne-Huiskes, and Laura den Dulk, eds., Flexible Working and Organisational Change. The Integration of Work and Personal Life. Cheltenham/Northampton: Edward Elgar: 119-135.

Perrons, Diane, Colette Fagan, Linda McDowell, Kath Rey and Kevin Ward. 2006. Gender Division and Working Time in the New Economy. Cheltenham, UK: Edward Elgar.

Pongratz, Hans G. and G. Günter Voß. 2003. "From Employeee to 'Entreployee': Towards a 'Self-Entrepreneurial' Work Force?” Concepts and Transformation 8 (3): 239-254.

Pratt, Andy C. 2000. "New Media, the New Economy and New Spaces". Geoforum 31: 425436.

Rehberg, Frank, Ursula Stöger and Detlev Sträter. 2002. Frauen in der Medienwirtschaft. Chancen und Hemmnisse für Frauenerwerbstätigkeit in einer prosperierenden Zukunftsbranche. München: R. Fischer.

Rüling, Anneli, Karsten Kassner and Peter Grottian. 2004. "Geschlechterdemokratie leben. Junge Eltern zwischen Familienpolitik und Alltagserfahrungen”. Aus Politik und Zeitgeschichte (supplement to the weekly journal "Das Parlament") B19: 11-18.

Satzer, Ralf. 2001. Nicht nur Traumjobs - vom Arbeiten und Verdienen in den Medien. Frankfurt a. M.: connexx.av.

Walby, Sylvia, Heidi Gottfried, Karin Gottschall and Mari Osawa, eds. 2007. Gendering the Knowledge Economy: Comparative Perspectives. Houndmills/Basingstoke: Palgrave Macmillan.

Windeler, Arnold, Anja Lutz and Carsten Wirth. 2000. Netzwerksteuerung durch Selektion Die Produktion von Fernsehserien in Projektnetzwerken. In Jörg Sydow and Arnold Windeler, eds., Steuerung von Netzwerken. Konzepte und Praktiken. Opladen/Wiesbaden:

Westdeutscher Verlag: 178-205.

Wixforth, Jürgen. 2003. Ungleichheitsmuster nach Alter und Geschlecht: erste Erklärungsansätze. Paper presented at the conference "Neue Medien - neue Arbeit? Hamburg im Vergleich mit internationalen Metropolen”. Hamburg, 16.06.2003.

Woods, Dorian. 2003. Das 'adult worker model' in den USA und Großbritannien. In Sigrid Leitner, Ilona Ostner and Margit Schratzenstaller, eds., Jahrbuch für Europa- und Nordamerika-Studien. Wiesbaden: VS Verlag für Sozialwissenschaften. Wiesbaden: VS Verlag für Sozialwissenschaften: 208-233. $(\leftarrow$ p. 71) 